\title{
Sphingosine 1-phosphate induced by hypoxia increases the expression of PAI-1 in HepG2 cells via HIF-1 $\alpha$
}

\author{
AKIMASA SANAGAWA $^{1}$, SOICHIRO IWAKI ${ }^{1}$, MOYOKO ASAI $^{1}$, DAISUKE SAKAKIBARA $^{1}$, \\ HIROAKI NORIMOTO $^{1}$, BURTON E. SOBEL ${ }^{2}$ and SATOSHI FUJII ${ }^{1,3}$ \\ ${ }^{1}$ Department of Molecular and Cellular Pathobiology and Therapeutics, Graduate School of Pharmaceutical Sciences, \\ Nagoya City University, Nagoya, Aichi 467-8603, Japan; \\ ${ }^{2}$ Cardiovascular Research Institute, University of Vermont, Colchester, VT 05446, USA
}

Received February 4, 2016; Accepted May 23, 2016

DOI: $10.3892 / \mathrm{mmr} .2016 .5451$

\begin{abstract}
Our group has recently reported that in the immortal human HepG2 liver cell line, sphingosine 1-phosphate (S1P) increases transcription of plasminogen activator inhibitor type-1 (PAI-1), the major physiological inhibitor of fibrinolysis, within $4 \mathrm{~h}$. The present study aimed to elucidate the molecular mechanisms underlying this effect. PAI-1 expression was measured by reverse transcription-quantitative polymerase chain reaction and immunoblotting. It was demonstrated that S1P increased PAI-1 promoter activity but did not increase the activity of promoters lacking the hypoxia responsive element (HRE) 2. In addition, S1P transiently increased the concentration of hypoxia inducible factor (HIF)-1 $\alpha$, a transcription factor capable of binding to HRE. When HIF-1 $\alpha$ was knocked down, the induction of transcription of PAI-1 by S1P was no longer observed. Sphingosine kinase (SPHK) activity is increased by hypoxia. It was demonstrated that increases in the concentration of the HIF-1 $\alpha$ protein induced by hypoxia were prevented by treatment with SPHK inhibitor or S1P receptor antagonists. Thus, modification of the induction of HIF-1 $\alpha$ by S1P, leading to increased transcription of PAI-1, may be an attractive therapeutic target for thrombosis and consequent inhibition of fibrinolysis associated with hypoxia.
\end{abstract}

\section{Introduction}

Plasminogen activator inhibitor type-1 (PAI-1) is the major physiological inhibitor of fibrinolysis and is implicated in

Correspondence to: Professor Satoshi Fujii, ${ }^{3}$ Present address: Department of Laboratory Medicine, Asahikawa Medical University, Midorigaoka Higashi 2-1-1-1, Asahikawa, Hokkaido 078-8510, Japan E-mail: sfujii@asahikawa-med.ac.jp

Abbreviations: HIF-1 $\alpha$, hypoxia inducible factor-1 $\alpha$; PAI-1, plasminogen activator inhibitor type-1; S1P, sphingosine 1-phosphate

Key words: hypoxia, hypoxia inducible factor, plasminogen activator inhibitor-1, sphingosine 1-phosphate diverse disorders, such as thrombosis, fibrosis and the vasculopathy associated with diabetes $(1,2)$. PAI-1 is expressed in vascular endothelial cells, vascular smooth muscle cells, myocytes, hepatocytes and adipocytes. Its expression can be modulated by tissue specific factors (3). PAI-1 has been found in plasma and platelets, as well as in conditioned media of endothelial cells and hepatocytes (4).

Our previous study demonstrated that in the human HepG2 liver cell line, sphingosine 1-phosphate (S1P) can promptly increase the transcription of PAI-1 (5). S1P, synthesized by sphingosine kinase (SPHK) acting on sphingosine, is a bioactive signaling molecule that regulates cell movement, differentiation, inflammation, angiogenesis and immunity through S1P receptors (6-9). S1P can be released from red blood cells, platelets and endothelial cells. Receptors of S1P are $\mathrm{G}$ protein-coupled receptors consisting of 5 sub types (6). In the PAI-1 3'-untranslated region (UTR), S1P contributes to RNA decay, thus, increased PAI-1 transcription due to S1P likely involves the promoter region (5).

It was recently reported that plasma S1P levels in patients were correlated with their body mass index and PAI-1 levels. When plasma S1P levels were corrected with hemoglobin or hematocrit, this correlation was no longer observed (10). In addition, in mouse 3T3-L1 adipocytes, $\mathrm{CoCl}_{2}$ was shown to promote S1P production and extracellular transport, and increase hypoxia inducible factor (HIF)-1 $\alpha$ and PAI-1 (10).

In HepG2 cells, hypoxia can increase transcription of PAI-1 by acting on the hypoxia responsive element (HRE) 2 of the PAI-1 promoter. Transcriptional factor HIF-1 $\alpha$ can complex with the aryl hydrocarbon receptor nuclear translocator and bind to HRE2 (11). HIF-1 $\alpha$ is a 'master regulator' of gene expression. Under conditions of hypoxia the activity of the oxygen-dependent enzyme, prolyl hydroxylase, is attenuated. Consequently, degradation of HIF-1 by the ubiquitin-proteasome pathway is inhibited (12).

SPHK1, the major enzyme involved in S1P synthesis, is a modulator of HIF-1 $\alpha$ during hypoxia in human cancer cells (13). Stimulation with $1 \% \mathrm{O}_{2}$ elevates $\mathrm{S} 1 \mathrm{P}$ in cultured human colon cancer cells $(14,15)$. Accordingly, S1P is likely to be pivotal in increasing PAI-1 induced by hypoxia. The results obtained in the present study suggest that in HepG2 cells, S1P induced by hypoxia is an essential component in the pathway 
leading to induction of HIF-1 $\alpha$ and hence increased transcription of PAI-1.

\section{Materials and methods}

Cell culture and reagents. Human hepatocarcinoma-derived HepG2 cells (American Type Culture Collection, Manassas, VA, USA) were grown in Dulbecco's modified Eagle's medium (DMEM, Wako Pure Chemical, Osaka, Japan) containing $4.5 \mathrm{mg} / \mathrm{ml}$ glucose and supplemented with $10 \%$ fetal bovine serum (Thermo Fisher Scientific, Inc., Waltham, MA, USA) at $37^{\circ} \mathrm{C}$ in $5 \% \mathrm{CO}_{2}$. Cells were grown to $80 \%$ confluency, washed with phosphate-buffered saline (PBS) and serum starved by incubating in serum-free DMEM containing $0.2 \%$ bovine serum albumin (BSA; Sigma-Aldrich, St. Louis, MO, USA) for 16 h. S1P (Enzo Life Sciences, Farmingdale, NY, USA) was added to the media to assess its effects on expression of mRNA and protein. In certain experiments, cells were cultured under hypoxic condition $\left(\begin{array}{lll}1 \% & \mathrm{O}_{2} \text { and } 5 \% & \left.\mathrm{CO}_{2}\right)\end{array}\right.$ in a low oxygen incubator $\left(\mathrm{CO}_{2} /\right.$ multi-gas incubator, Astec,

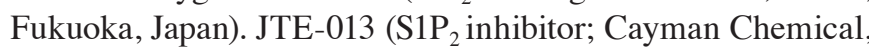
Ann Arbor, MI, USA) and VPC-23019 (S1P 1/3 $_{\text {inhibitor; }}$ Avanti Polar Lipids, Alabaster, AL, USA) were dissolved in dimethyl sulfoxide (DMSO). They were added to the medium $30 \mathrm{~min}$ prior to exposure of the cells to hypoxia or stimulation by S1P at concentrations of $10 \mu \mathrm{M}$. An SPHK inhibitor, SKI [2-( $p$-Hydroxyanilino)-4-( $p$-chlorophenyl) thiazole $\mathrm{HCl}$; Merck Bioscience, Darmstadt, Germany] was also dissolved in DMSO and added to the medium 30 min before induction of hypoxia at a concentration of $10 \mu \mathrm{M}$.

Reverse transcription-quantitative polymerase chain reaction. Total RNA was isolated with the use of the Tripure Isolation Reagent (Roche Diagnostics, Basel, Switzerland) and converted to cDNA with the use of PrimeScript RT reagent kits (cat. no. RR037A; Takara Bio Inc., Otsu, Japan). qPCR was performed with FastStart Universal SYBR Green Master (ROX) (Roche Diagnostics) on a Thermal Cycler Dice Real Time system (cat. no. TP900; Takara Bio Inc.). When the reaction had proceeded and the amplification and melting curves had been confirmed, mRNA was quantified with the use of the $\Delta \Delta \mathrm{Cq}$ method as described previously (16). The reactions were performed as follows: $95^{\circ} \mathrm{C}$ for $10 \mathrm{~min}$, then $95^{\circ} \mathrm{C}$ for $15 \mathrm{sec}$ and $60^{\circ} \mathrm{C}$ for $1 \mathrm{~min}$ for 40 cycles. The primers used for qPCR were as follows: Forward: 5'-TGATGGCTCAGA CCAACAAG-3' and reverse: 5'-CAGCAATGAACATGC TGAGG-3' for human PAI-1; and forward: 5'-TCATCCAAG AAGCCCTAACG-3' and reverse: 5'-CGCTTTCTCTGAGCA TTCTG-3' for human HIF-1 $\alpha$. The human $\beta$-actin primer set (cat. no. HA067803) was purchased from Takara Bio Inc. and used as a control for normalization.

Immunobloting. PAI-1 protein in conditioned media was quantified as described previously (5). $\beta$-actin and HIF- $1 \alpha$ in cell lysates were assayed as follows: HepG2 cells were washed with PBS and lysed with lysis buffer [62.5 mmol/l Tris- $\mathrm{HCl}$ (pH 6.8), 2\% sodium dodecyl sulfate (SDS) and 10\% glycerol]. The lysates were centrifuged at $13,000 \mathrm{x} \mathrm{g}$ for $5 \mathrm{~min}$ at $4^{\circ} \mathrm{C}$ to remove the cell debris. Samples of supernatant fractions were subjected to SDS-polyacrylamide gel electrophoresis (PAGE) with the use of 8 or $10 \%$ running gels. After quantification of concentrations of protein with bicinchoninic acid protein assay kits (Thermo Fisher Scientific, Inc.), samples were diluted with 1X SDS sample buffer [62.5 mM Tris-HCl (pH 6.8), 2\% SDS, $10 \%$ glycerol, 5\% 2-mercaptoethanol and a trace amount of bromophenol blue] and incubated at $37^{\circ} \mathrm{C}$ for $5 \mathrm{~min}$. Equal amounts of protein were separated by SDS-PAGE and transferred to Immobilon-P polyvinylidene difluoride membranes (Millipore, Billerica, MA, USA). Membranes were blocked in 3\% skim milk in Tris-buffered saline. Membranes were incubated with mouse anti-HIF-1 $\alpha$ IgG (1:5,000 dilution; cat. no. NB100-105; Novus Biologicals LLC, Littleton, $\mathrm{CO}$, USA), or mouse anti- $\beta$-actin $\operatorname{IgG}(1 ; 20,000$ dilution; cat. no. A5441 Sigma-Aldrich) for $18 \mathrm{~h}$, and then incubated with peroxidase-conjugated goat anti-mouse $\operatorname{IgG}(1: 5,000$ dilution for HIF-1 and 1:10,000 dilution for actin detection; cat. no. NA9310; GE Healthcare, Buckinghamshire, England) for $1 \mathrm{~h}$. Labeling was detected with enhanced chemiluminescence-Plus reagents (GE Healthcare) or the SuperSignal West Femto Chemiluminescent Substrate (Thermo Fisher Scientific, Inc.) and the use of a photoimager LAS-3000 mini (Fujifilm, Tokyo, Japan). Images were analyzed with Image Gauge software (version 4.0; Fujifilm).

Plasmid constructs. The plasmids used were gifts from Dr Imagawa (Department of Cardiovascular Medicine, Hokkaido University, Sapporo, Japan). pGL3-basic vector (Promega Corporation, Madison, WI, USA) containing the PAI-1 gene promoter region $(-825$ to +42$)$ (designated as P-1) was used as previously described (5). PAI-1 gene promoter area fragments (P-2, -659 to $+42 ; \mathrm{P}-3,-536$ to $+42 ; \mathrm{P}-4,-360$ to +42 ; P-5, -302 to +42 ; P-6, -205 to $+42 ; \mathrm{P}-7,-165$ to $+42 ; \mathrm{P}-8,-115$ to +42 and $\mathrm{P}-9,-60$ to +42 ) were constructed in pGL3-control vectors (Promega Corporation) $(17,18)$. All the promoters were characterized by sequencing.

Transfection and luciferase assays. For measuring activity of the promoter region of the PAI-1 gene, DNA transfection and luciferase assays were performed as previously described (4). HepG2 cells were inoculated on 12 -well plates at $50 \%$ confluence and preincubated in serum free DMEM containing $0.2 \%$ BSA. Transient transfection was performed with the lipofection method with the use of Lipofectamine LTX (Thermo Fisher Scientific, Inc.). Co-transfections were performed with $1 \mathrm{mg}$ each of the PAI-1 promoter firefly luciferase fusion DNA reporter constructs in pGL3-basic vector (Promega Corporation) and 5 ng control pRL-TK vectors (Promega Corporation). After $5 \mathrm{~h}$, the cells were cultured in serum-starved media for $18 \mathrm{~h}$, stimulated with S1P or hypoxia for $24 \mathrm{~h}$ and harvested. Luciferase activity was detected in cell extracts with the Passive Lysis Buffer with the use of the Dual-Luciferase Reporter Assay system (Promega Corporation) and a luminometer (GloMax 20/20n, Promega Corporation). Normalized luciferase activity was calculated as the ratio of firefly luciferase activity to control Renilla luciferase activity. Results for each reporter construct were expressed as the fold induction compared with results in transfected, unstimulated cells.

RNA interference. Control small interfering (si)RNA (MISSON siRNA Universal Negative Control) and human 
A

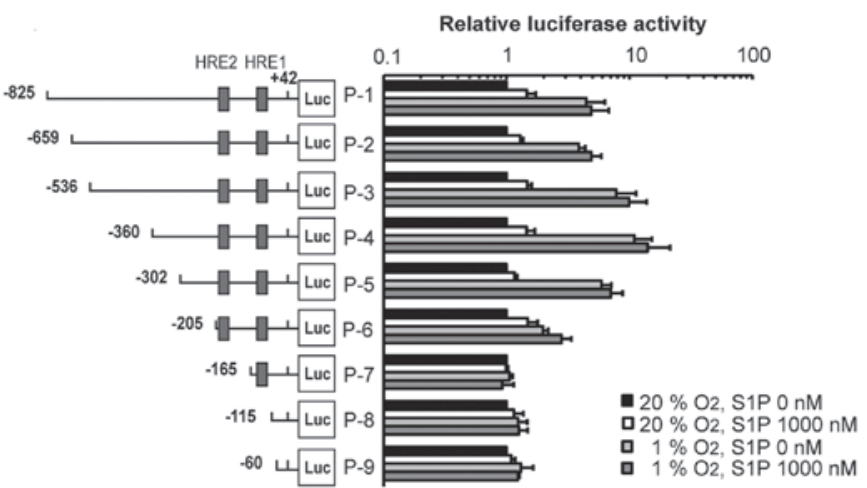

B

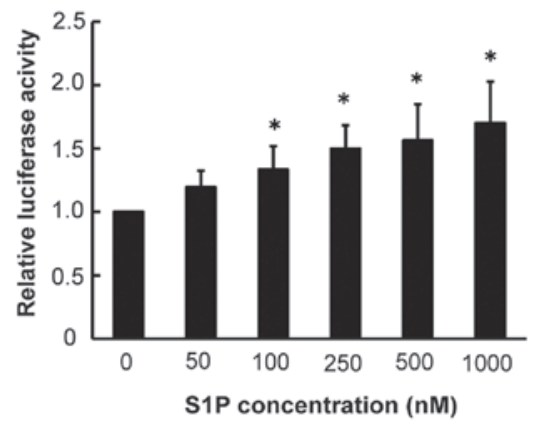

D

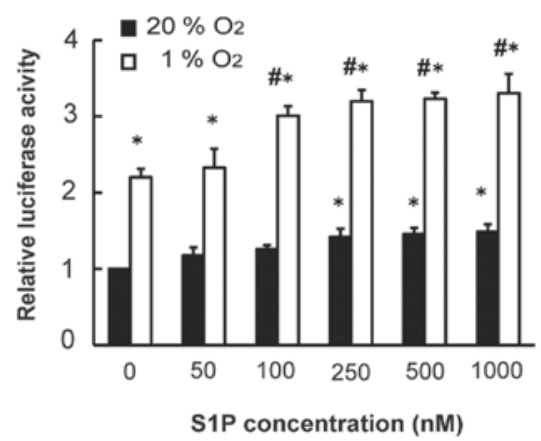

C

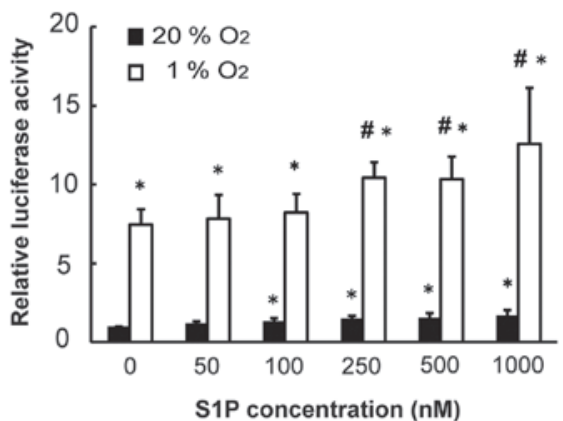

$\mathbf{E}$

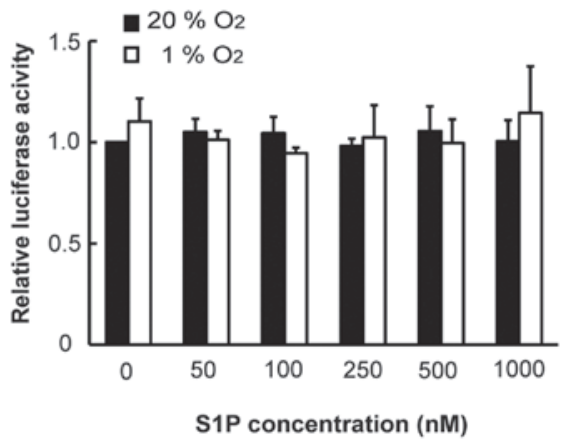

F

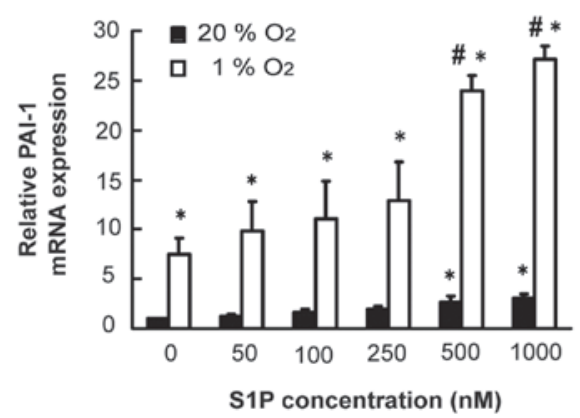

Figure 1. Hypoxia and S1P increase PAI-1 promoter activity through HRE2. HepG2 cells were co-transfected with $1 \mu \mathrm{g}$ each of the PAI-1 promoter area firefly luciferase fusion DNA reporter constructs (P-1 to P-9) in pGL3-basic vector and $5 \mathrm{ng}$ control pRL-TK vector. After $5 \mathrm{~h}$, the cells were serum-starved for $18 \mathrm{~h}$, stimulated with S1P (1,000 nM), cultured in serum-free DMEM under hypoxic conditions for $24 \mathrm{~h}$ and harvested. Luciferase activity was detected in cell extracts. (A) Locations of HRE1 and HRE2 are shown. (B) Cells were transfected with P-1 reporter construct and treated with S1P. After 24 h, luciferase activity was detected (n=3, "P<0.05 compared with $0 \mathrm{nM}$ ). (C) Cells were transfected with a P-1 reporter construct and subjected to hypoxia and S1P (at the indicated concentrations). After $24 \mathrm{~h}$ luciferase activity was detected $\left(\mathrm{n}=8,{ }^{*} \mathrm{P}<0.05\right.$ compared with normoxia and $0 \mathrm{nM},{ }^{*} \mathrm{P}<0.05$ compared with hypoxia and $\left.0 \mathrm{nM}\right)$. (D) Cells were transfected with $\mathrm{P}-6$ reporter construct and subjected to hypoxia and S1P (at the indicated concentrations). After $24 \mathrm{~h}$, luciferase activity was detected ( $\mathrm{n}=3$, ${ }^{\mathrm{P}} \mathrm{P}<0.05$ compared with normoxia and $0 \mathrm{nM},{ }^{,} \mathrm{P}<0.05$ compared with hypoxia and $0 \mathrm{nM}$ ). (E) Cells were transfected with P-7 reporter construct and subjected to hypoxia and S1P (at the indicated concentrations). After $24 \mathrm{~h}$, luciferase activity was detected. (F) Cells were stimulated with hypoxia and S1P (the indicated concentration) for $3 \mathrm{~h}$. Total RNA was subjected to reverse transcription-quantitative polymerase chain reaction for detection of PAI-1 mRNA ( $\mathrm{n}=3,{ }^{*} \mathrm{P}<0.05$ compared with normoxia and $0 \mathrm{nM}$, ${ }^{*} \mathrm{P}<0.05$ compared with hypoxia and $0 \mathrm{nM}$ ). S1P, sphingosine 1-phosphate; PAI-1, plasminogen activator inhibitor type-1; HRE, hypoxia responsive element.

HIF1A (HIF-1 $\alpha)$ siRNA (SASI_Hs02_00332063) were purchased from Sigma-Aldrich. siRNA (75 pmol) was transfected to HepG2 cells by reverse transfection with the use of
Lipofectamine RNAiMAX (Thermo Fisher Scientific, Inc.). After $48 \mathrm{~h}$, cells were serum-starved for $16 \mathrm{~h}$ and then stimulated under hypoxic conditions and by S1P for $6 \mathrm{~h}$ and $4 \mathrm{~h}$, 


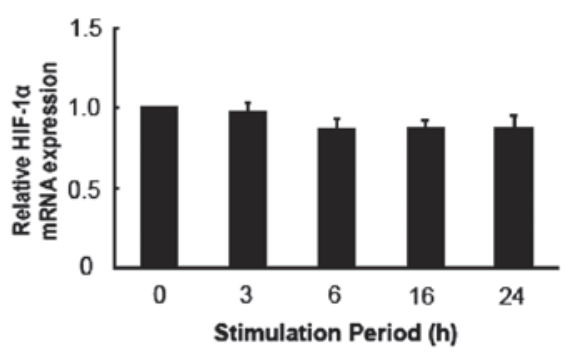

C

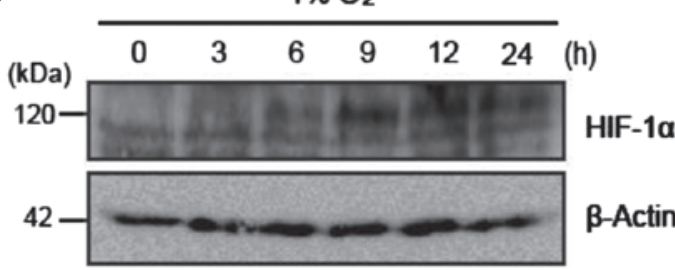

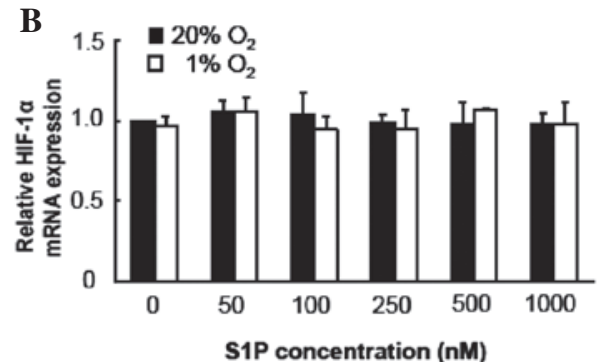

D

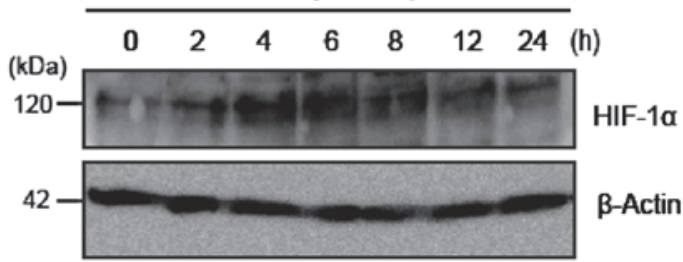

E

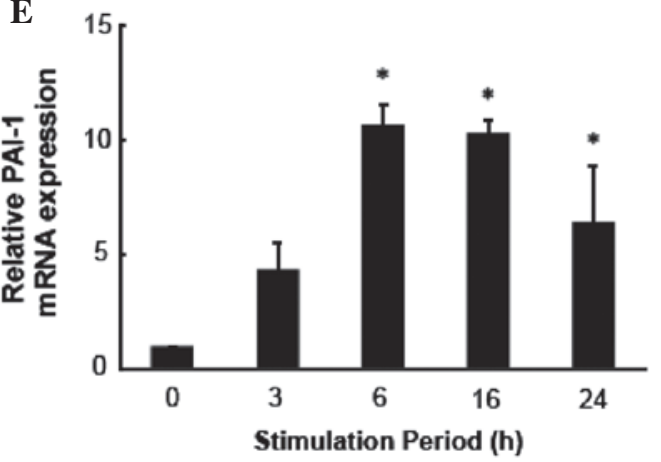

F

$20 \% \mathrm{O}_{2}$

$1 \% \mathrm{O}_{2}$

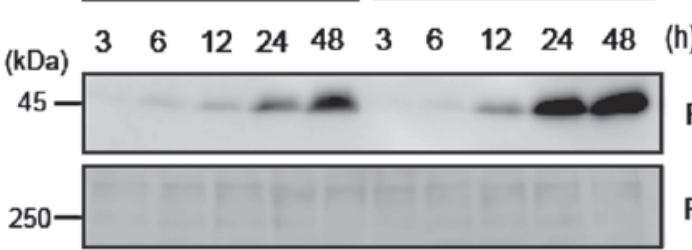

PAl-1

Ponceau S

Figure 2. S1P transiently increases HIF-1 $\alpha$ protein. (A and B) Cells were exposed to hypoxia, S1P or combination of both for $3 \mathrm{~h}$ and total RNA was prepared and subjected to RT-qPCR for detection of HIF-1 $\alpha$ mRNA. (C) HepG2 cells were exposed to hypoxia and cell lysates were subjected to western blotting for detection of HIF-1 $\alpha$ protein. (D) HepG2 cells were exposed to S1P $(500 \mathrm{nM})$, and cell lysates were subjected to western blotting for detection of HIF-1 $\alpha$ protein. (E) Cells were exposed to hypoxia and total RNA was prepared and subjected to RT-qPCR for detection of PAI-1 mRNA ( $\mathrm{n}=3$, "P $<0.05$ compared with $0 \mathrm{~h}$ ). (F) Cells were exposed to hypoxia and conditioned media were subjected to western blotting for detection of PAI-1 protein. Ponceau S staining was used as a loading control. S1P, sphingosine 1-phosphate; PAI-1, plasminogen activator inhibitor type-1; HIF-1 $\alpha$, hypoxia inducible factor-1 $\alpha$; RT-qPCR, reverse transcription-quantitative polymerase chain reaction.

respectively. Cells and media were collected and subjected to RT-qPCR and immunoblotting, respectively.

Measurement of SPHK activity. In vitro sphingosine kinase assays were performed as described previously (19), with minor modifications. Cells were lysed by sonication in assay buffer containing $20 \mathrm{mM}$ Tris- $\mathrm{HCl}$ ( $\mathrm{pH}$ 7.5), $0.25 \mathrm{mM}$ EDTA, $12 \mathrm{mM}$ b-glycerophosphate, $1 \mathrm{mM}$ sodium pyrophosphate, $5 \mathrm{mM}$ sodium fluoride, $5 \%$ glycerol, $1 \mathrm{X}$ protease inhibitor cocktail (Complete ${ }^{\mathrm{TM}}$ EDTA free; Roche Diagnostics), $1 \mathrm{mM}$ phenylmethylsulfonyl fluoride, $5 \mathrm{mM}$ sodium orthovanadate, $2 \mathrm{mM}$ dithiothreitol and $0.5 \mathrm{mM}$ 4-deoxypyridoxine. After removal of cell debris by centrifugation at $1,000 \mathrm{x} \mathrm{g}$ for $3 \mathrm{~min}$ at $4^{\circ} \mathrm{C}$, the total lysates were subjected to an in vitro sphingosine kinase assay. Volumes of samples (50 $\mu \mathrm{g}$ protein) were adjusted to $190 \mu \mathrm{l}$ with assay buffer and mixed with $10 \mu \mathrm{M}$ D-erythro-sphingosine (dissolved in 5\% Triton X-100). The reactions were initiated by adding $2 \mu \mathrm{Ci}$ of $\left[\gamma_{-}{ }^{32} \mathrm{P}\right] \mathrm{ATP}$ (200 nmol, Institute of Isotopes Co., Ltd., Budapest, Hungary), in $200 \mathrm{mM} \mathrm{MgCl}_{2}$, followed by incubation at $37^{\circ} \mathrm{C}$ for $15 \mathrm{~min}$. Reactions were terminated by addition of $750 \mu \mathrm{l}$ chloroform/methanol/HCl (100:200:1, v/v). The organic phase was separated from the aqueous phase by adding $250 \mu \mathrm{l}$ chloroform and $250 \mu \mathrm{l}$ of $1 \% \mathrm{KCl}$. The labeled lipids in the organic phase were recovered by centrifugation $\left(3,500 \mathrm{rpm}, 4^{\circ} \mathrm{C}, 3 \mathrm{~min}\right)$, dried and suspended in chloroform/methanol (2:1, v/v). Lipids were separated on Silica Gel G60 high performance TLC plates (Merck Bioscience) with 1-butanol/acetic acid/water 

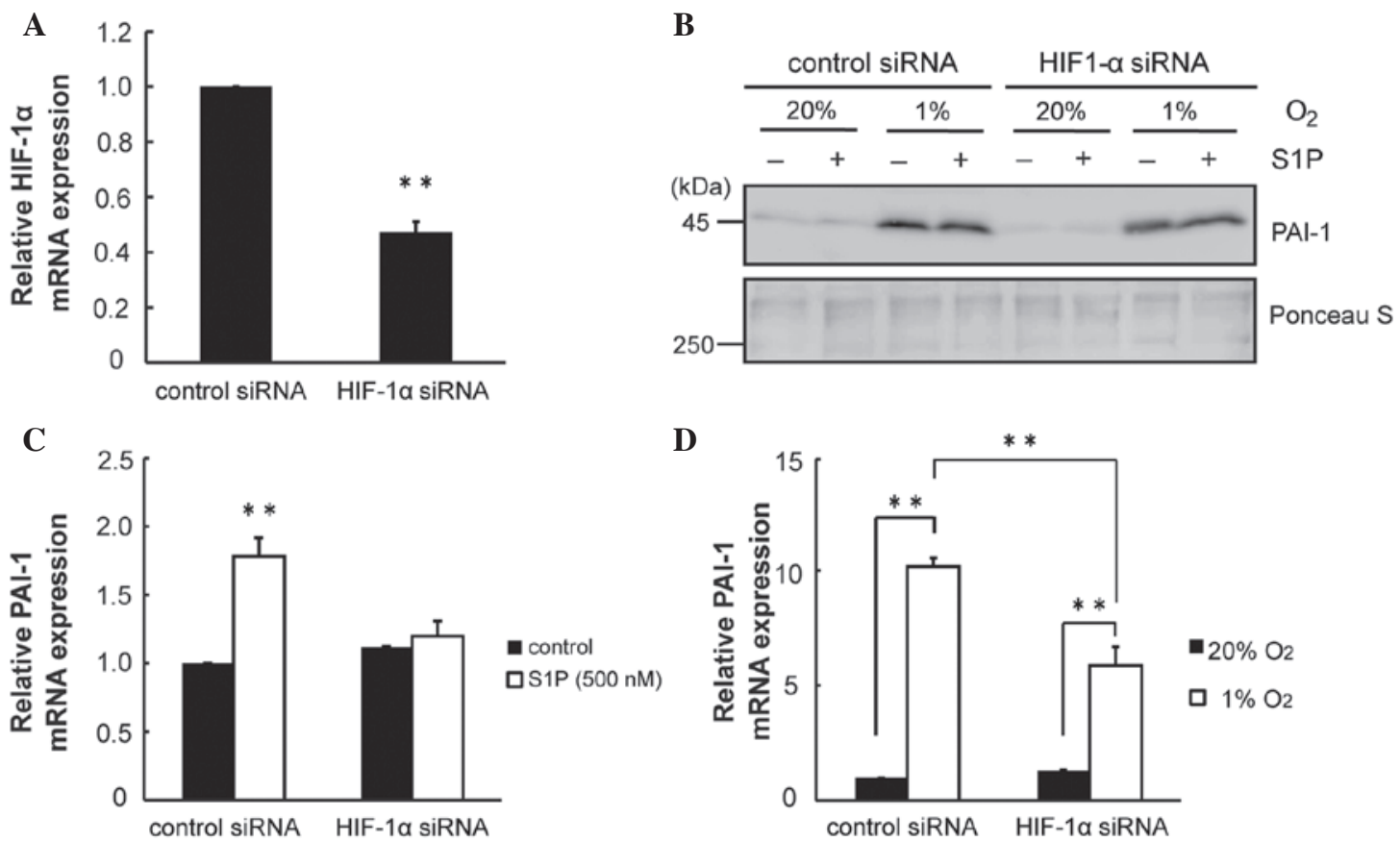

Figure 3. HIF-1 $\alpha$ is involved in the increase of PAI-1 induced by hypoxia and S1P. (A) HepG2 cells were transfected with HIF-1 $\alpha$ siRNA (75 pmol). After $24 \mathrm{~h}$, the expression of HIF- $1 \alpha$ mRNA was determined by RT-qPCR ( $n=3,{ }^{* *} \mathrm{P}<0.01$ compared with control). (B) After transfection with HIF-1 $\alpha$ siRNA, cells were serum-starved for $16 \mathrm{~h}$. Then, cells were subjected to hypoxia and S1P $(500 \mathrm{nM})$ for $24 \mathrm{~h}$. Conditioned media were collected. PAI-1 was quantified by western blot analysis. Ponceau S staining was used as a loading control. (C) After transfection with HIF-1 $\alpha$ siRNA, cells were serum-starved for $16 \mathrm{~h}$. Then, cells were stimulated with S1P $(500 \mathrm{nM})$ for $4 \mathrm{~h}$. Total RNA was extracted and subjected to RT-qPCR for detection of PAI-1 mRNA ( $\mathrm{n}=3$, $\left.{ }^{* * *} \mathrm{P}<0.01\right)$. (D) After transfection with HIF-1 $\alpha$ siRNA, cells were serum-starved for $16 \mathrm{~h}$. Then, cells were subjected to hypoxia for $6 \mathrm{~h}$. Total RNA was extracted and subjected to RT-qPCR for detection of PAI-1 mRNA ( $\left.\mathrm{n}=3,{ }^{* *} \mathrm{P}<0.01\right)$. HIF-1 $\alpha$, hypoxia inducible factor-1 $\alpha$; PAI-1; plasminogen activator inhibitor type-1; S1P, sphingosine 1-phosphate; siRNA, small interfering RNA; RT-qPCR, reverse trancscription-quantitative polymerase chain reaction.

(3:1:1, v/v). Radioactivity associated with S1P were quantified using a Bio-Imaging Analyzer, BAS1800II (Fujifilm).

Statistical analysis. Data are expressed as the mean \pm standard deviation. After verification that the data were normally distributed, differences were assessed with Welch's t-tests. Multiple comparisons between groups were made by Tukey-Kramer test. $\mathrm{P}<0.05$ was considered to indicate a statistically significant difference.

\section{Results}

Hypoxia and SIP increase PAI-1 promoter activity in relation to HRE2 and increase transcription of PAI-1. To determine the association of S1P with transcription of PAI-1, the effects of S1P on PAI-1 promoter activity were determined using a luciferase assay and a PAI-1 promoter construct. Hypoxia and S1P increased the luciferase activity of PAI-1 promoter constructs $(\mathrm{P}<0.05$; $\mathrm{P}-1$ to $\mathrm{P}-6)$. No effects were observed in P-7 to P-9 (Fig. 1A). S1P increased the luciferase activity of PAI-1 promoter constructs (P-1) in a dose-dependent manner (Fig. 1B). With the P-1 and P-6 constructs, S1P had additive effects with hypoxia in inducing luciferase activity $(\mathrm{P}<0.05$; Fig. 1C and D). However, in the P-7 construct, without HRE2 S1P, hypoxia failed to induce luciferase activity (Fig. 1E). In addition, S1P and hypoxia increased PAI-1 mRNA in an additive manner (Fig. 1F). These results suggested that hypoxia and S1P increased PAI-1 promoter activity in a HRE2-dependent manner and increased transcription of PAI-1.
Induction of HIF-1 $\alpha$ by SIP is transient compared with that observed with induction by hypoxia. Hypoxia and S1P were not identified to alter the expression of HIF-1 $\alpha$ mRNA (Fig. 2A and B). Thus, the effects of S1P on HIF- $1 \alpha$ protein and PAI-1 mRNA were elucidated to determine the differences between the effects of S1P and hypoxia. Hypoxia and S1P increased HIF-1 $\alpha$ protein levels (Fig. 2C and D) and hypoxia was shown to increase PAI-1 mRNA ( $\mathrm{P}<0.05$; Fig. 2E). The increase in PAI-1 protein with hypoxia was sustained (Fig. 2F). The increase in HIF-1 $\alpha$ with S1P was transient (Fig. 2D). Thus, induction of HIF-1 $\alpha$ by S1P was transient compared with that observed with induction by hypoxia.

Induction of PAI-1 by hypoxia and SIP involves HIF-1 $\alpha$. It was investigated whether the S1P-induced increase in PAI-1 transcription involves HIF- $1 \alpha$ using siRNA. HIF- $1 \alpha$ siRNA reduced HIF- $1 \alpha$ mRNA by 0.5 -fold (P<0.01; Fig. 3A). HIF- $1 \alpha$ siRNA modestly prevented the increase in PAI-1 protein induced by hypoxia and S1P (Fig. 3B). HIF-1 $\alpha$ siRNA prevented the increase in PAI-1 mRNA induced by S1P $(\mathrm{P}<0.01$; Fig. 3C). Furthermore, HIF-1 $\alpha$ siRNA prevented the increase in PAI-1 mRNA induced by hypoxia (Fig. 3D). The results suggested that the induction of PAI-1 by hypoxia and S1P involved HIF-1 $\alpha$.

Under conditions of hypoxia, SIP increases HIF-la in an autocrine and paracrine manner. It was then investigated whether alterations of HIF-1 $\alpha$ induced by hypoxia involves S1P. Hypoxia was observed to increase the enzymatic activity 

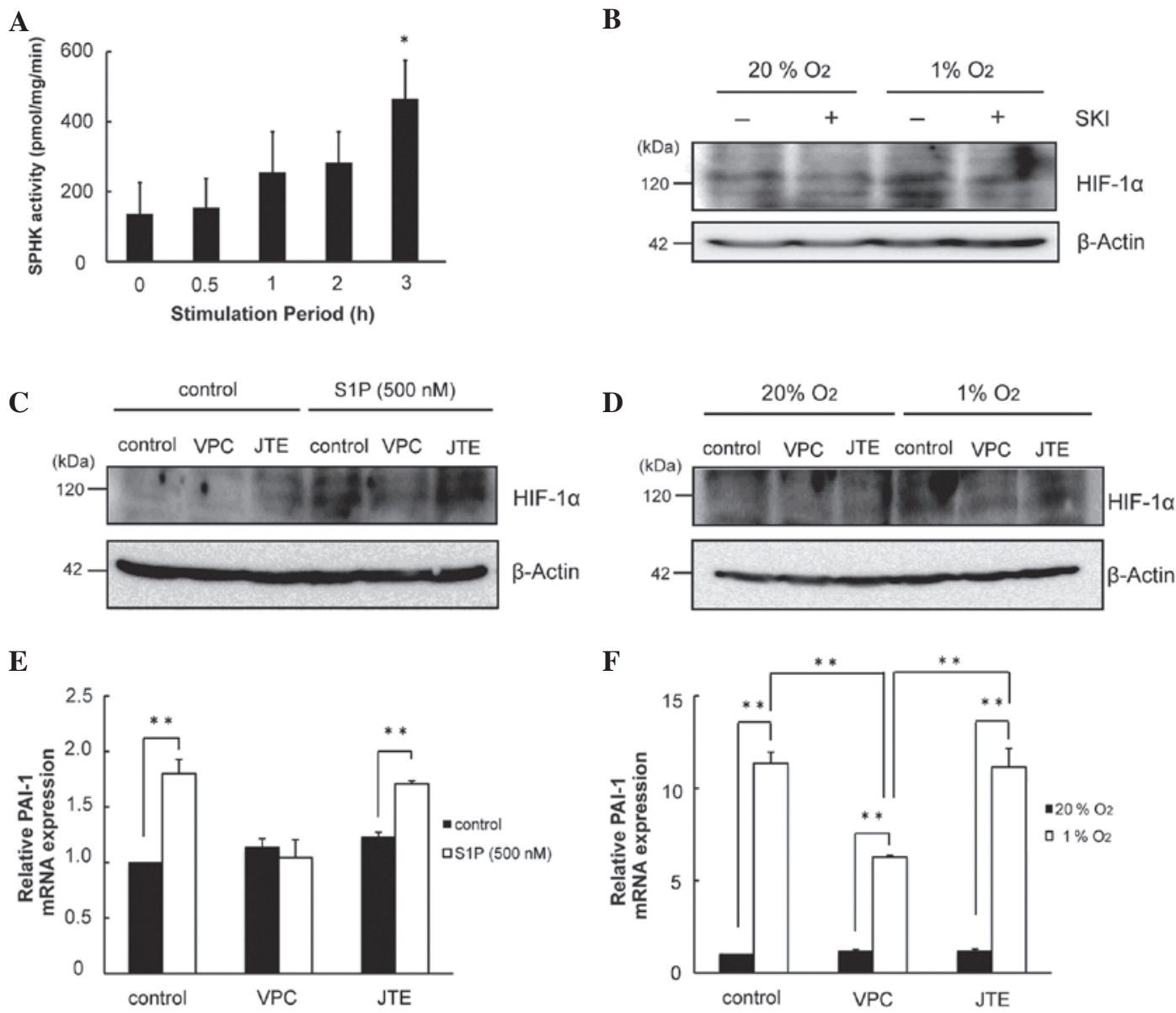

Figure 4. S1P produced by hypoxia contributes to the increase in HIF-1 $\alpha$ protein. (A) Cell lysates were collected following exposure to hypoxia Proteins $(50 \mu \mathrm{g})$ were incubated with $1 \mathrm{mM}\left[\gamma^{-32} \mathrm{P}\right]$-ATP and $50 \mu \mathrm{M}$ sphingosine for $15 \mathrm{~min}$ at $37^{\circ} \mathrm{C}$. Lipids were extracted and separated by thin-layer chromatography. Radioactivity associated with S1P was quantified using a Bio-Imaging Analyzer BAS-1800II ( $\mathrm{n}=3$, " $\mathrm{P}<0.05 \mathrm{compared}$ with $0 \mathrm{~h}$ ). (B) Cells were pretreated with SKI for $30 \mathrm{~min}$, exposed to hypoxia for $6 \mathrm{~h}$, and subjected to western blot analysis for detection of HIF-1 $\alpha$ protein. (C) Cells were pretreated with S1P receptor antagonists for $30 \mathrm{~min}$, exposed to S1P $(500 \mathrm{nM})$ for $4 \mathrm{~h}$, and subjected to western blot analysis for the detection of HIF-1 $\alpha$ protein. (D) Cells were pretreated with S1P receptor antagonists for $30 \mathrm{~min}$, exposed to hypoxia for $6 \mathrm{~h}$, and subjected to western blot analysis for the detection of HIF-1 $\alpha$ protein. (E) Cells were pretreated with S1P receptor antagonists for 30 min, exposed to S1P (500 nM) for $4 \mathrm{~h}$, and total RNA subjected to RT-qPCR for detection of PAI-1 mRNA $\left(n=3,{ }^{* *} \mathrm{P}<0.01\right)$. (F) Cells were pretreated with S1P receptor antagonists for 30 min, exposed to hypoxia for $6 \mathrm{~h}$, and total RNA subjected to RT-qPCR for detection of PAI-1 mRNA ( $\left.\mathrm{n}=3,{ }^{* *} \mathrm{P}<0.01\right)$. S1P, sphingosine 1-phosphate; HIF-1 $\alpha$, hypoxia inducible factor-1 $\alpha$; PAI-1; plasminogen activator inhibitor type-1; RT-qPCR, reverse trancscription-quantitative polymerase chain reaction; SPHK, sphingosine kinase.

of SPHK (P<0.05; Fig. 4A). The increase in HIF-1 $\alpha$ protein induced by hypoxia was attenuated by inhibitors of SPHK (Fig. 4B). Increases in HIF-1 $\alpha$ induced by hypoxia and S1P were blunted by inhibitors of $\mathrm{S}_{1 / 3}$ (Fig. $4 \mathrm{C}$ and D). Increases in PAI-1 mRNA induced by S1P and hypoxia were diminished by inhibitors of $\mathrm{S}_{1} \mathrm{P}_{1 / 3}(\mathrm{P}<0.01$; Fig. $4 \mathrm{E}$ and $\mathrm{F})$. Thus, S1P increased HIF-1 $\alpha$ in an autocrine and paracrine manner under conditions of hypoxia.

\section{Discussion}

In the present study, hypoxia and S1P acted on the same region of the PAI-1 promoter. In HepG2 cells, PAI-1 promoter regions have previously been investigated $(11,17,18,20-23)$. The region responsive to S1P contained HRE2. As S1P and hypoxia increased PAI-1 promoter activity in an additive manner, it is likely that S1P and hypoxia share a common transcription factor and increase PAI-1. HIF-1 $\alpha$ binds to PAI-1 HRE2 $(11,22)$. In HepG2 cells, increases in HIF-1 $\alpha$ protein in response to hypoxia were persistent. By contrast, the S1P-induced increase in HIF-1 $\alpha$ protein, although rapid, was transient, which was consistent with the results of a previous study (11). An increase in PAI-1 protein in conditioned media by hypoxia became apparent at $6 \mathrm{~h}$.

S1P did not significantly increase PAI-1 protein in the media. Therefore, HIF-1 $\alpha$ protein and PAI-1 mRNA were investigated. Transcription of PAI-1 induced by S1P was strongly inhibited by knockdown of HIF-1 $\alpha$, suggesting that S1P increases transcription of PAI-1 via modulation of HIF-1 $\alpha$. Increases in PAI-1 transcription following hypoxia were partially diminished by HIF- $1 \alpha$ knockdown, suggesting that HIF-1 $\alpha$ is involved in PAI-1 transcription in a diverse manner under hypoxia and S1P.

In human cancer cells, hypoxia increases the activity of SPHK. S1P released from such cells can function in an autocrine or paracrine manner $(13,24)$. Temporally similar, rapid increases in SPHK activity induced by hypoxia were observed in HepG2 cells. The increases in SPHK1 protein preceded 
the increases in HIF-1 $\alpha$ protein. Furthermore, knockdown of SPHK1 prevented the hypoxia-induced increases in HIF-1 $\alpha$ protein (13). Inhibitors of SPHK also prevented the increases in HIF-1 $\alpha$ protein induced by hypoxia. These results suggest that SPHK or products of SPHK are central to hypoxia-induced increases in HIF-1 $\alpha$. Hypoxia and/or S1P did not affect HIF-1 $\alpha$ mRNA. However, hypoxia and S1P increased HIF-1 $\alpha$ protein.

Even in the absence of hypoxia, S1P increases HIF-1 $\alpha$ protein via activation of the phosphoinositide 3 -kinase pathway independent of von Hippel-Lindau (VHL) tumor suppressor protein (pVHL) in mouse endothelial cells (25). By contrast, hypoxia induces increases in SPHK1 activity that increase HIF-1 $\alpha$ protein via pVHL in human cancer cells (13). In human follicular thyroid cancer cells, S1P stabilized the HIF-1 $\alpha$ protein independent of pVHL (26). Conversely, S1P activated translational regulators eIF-4E and p70S6K, which are known to control HIF-1 $\alpha$ synthesis (26). The results obtained in the present study support the view that S1P and hypoxia increase transcription of PAI-1 in an additive manner.

$\mathrm{S}_{\mathrm{P}} \mathrm{P}_{1 / 3}$ inhibitors prevented the increases in HIF-1 $\alpha$ protein induced by hypoxia and S1P. Downstream transcription of PAI-1 was attenuated. These results suggested that S1P produced by SPHK is involved in the early stages of increases in HIF-1 $\alpha$ protein induced by hypoxia. As HepG2 cells express $\mathrm{S}_{1} \mathrm{P}_{1}, \mathrm{~S}_{1} \mathrm{P}_{2}$ and $\mathrm{S}_{1} \mathrm{P}_{4}$ subtypes (5), it is likely that increases in PAI-1 induced by S1P are mediated by $\mathrm{S}_{1} \mathrm{P}_{1}(5-6)$. However, other S1P receptor subtypes have been demonstrated to also be involved $(10,25,26)$.

S1P also affects transcriptional regulation with miRNA and RNA binding protein. S1P acts on PAI-1 mRNA 3'-UTR and regulates RNA decay (5). At high concentrations of S1P, PAI-1 is increased. Indeed, in humans, plasma S1P level and plasma PAI-1 levels are positively correlated (10).

Sphingolipids are known to be associated with thrombosis. In Fabry disease, a sphingolipid storage disorder, plasma S1P level is increased (27) and thrombosis results from cerebral vasculopathy (28). $\mathrm{Npcl}$ is the gene responsible for Niemann-Pick disease and, in $\mathrm{ApoE}^{-/}, \mathrm{Npcl}^{-/-}$mice spontaneous atherothrombosis and medial degradation are observed (29). Furthermore, S1P is abundantly present in platelets and red blood cells $(30,31)$. It is likely that the S1P concentration can be increased with platelet activation or red blood cell destruction. For instance, hemoglobin released upon hemolysis can activate platelets, and thrombosis is the major cause of death in paroxysmal nocturnal hemoglobinuria, where chronic hemolysis is observed (32). In thrombotic thrombocytopenic purpura, thrombus formation is facilitated and red blood cells are mechanically destroyed. In these diseases or animal models PAI-1 is shown to be increased (29,33-35), suggesting that excessive S1P can increase PAI-1 and shift the fibrinolytic balance toward thrombosis.

In normal human plasma, the S1P concentration is $100-300 \mathrm{nM}$ (30) and is maintained by the release from platelets, red blood cells and endothelium (31). Thrombus formation, tissue hypoxia and release of S1P from activated platelets are closely associated $(30,31)$. Hypoxia can induce the release of S1P from diverse tissues, leading to a environment characterized by high levels of S1P. Associations between the increase in PAI-1, and hypoxia and S1P may underlie the formation of thrombus and create a vicious cycle. Induction of
PAI-1 and diminution of fibrinolysis by S1P under conditions of hypoxia may be attenuated by pharmacologic interventions focused on inhibition of S1P receptors.

In conclusion, the present study demonstrated that S1P induced by hypoxia increases the expression of PAI-1 in HepG2 cells via HIF-1 $\alpha$ and that inhibition of S1P receptors may be an attractive therapeutic target and ameliorate thrombosis following hypoxia.

\section{Acknowledgements}

This study was supported in part by grants-in-aid for scientific research from the Ministry of Education, Science, Sport and Culture of Japan. The authors would like to thank Professor Shin-ichi Hoshino (Department of Biological Chemistry, Graduate School of Pharmaceutical Sciences, Nagoya City University, Nagoya, Japan) for useful advice and helpful discussions, and Ms. Rebecca Aksdal for assistance in preparation of the manuscript.

\section{References}

1. Lucore CL and Sobel BE: Interactions of tissue type plasminogen activator with plasma inhibitors and their pharmacologic implications. Circulation 77: 660-669, 1988.

2. Sobel BE, Taatjes DJ and Schneider DJ: Intramural plasminogen activator inhibitor type-1 and coronary atherosclerosis. Arterioscler Thromb Vasc Biol 23: 1979-1989, 2003.

3. Eren M, Painter CA, Gleaves LA, Schoenhard JA, Atkinson JB, Brown NJ and Vaughan DE: Tissue- and agonist-specific regulation of human and murine plasminogen activator inhibitor-1 promoters in transgenic mice. J Thromb Haemost 1: 2389-2396, 2003.

4. Asakura T, Iwaki S, Okada H, Sobel BE and Fujii S: Posttranscriptional regulation of expression of plasminogen activator inhibitor type-1 by cAMP in HepG2 liver cells. J Biochem 150: 687-694, 2011.

5. Iwaki S, Yamamura S, Asai M, Sobel BE and Fujii S: Posttranscriptional regulation of expression of plasminogen activator inhibitor type-1 by sphingosine 1-phosphate in HepG2 liver cells. Biochim Biophys Acta 1819: 1132-1141, 2012.

6. Chun J, Hla T, Lynch KR, Spiegel S and Moolenaar WH: International union of basic and clinical pharmacology. LXXVIII. Lysophospholipid receptor nomenclature. Pharmacol Rev 62: 579-587, 2010.

7. Spiegel S, English D and Milstien S: Sphingosine 1-phosphate signaling: Providing cells with a sense of direction. Trend Cell Biol 12: 236-242, 2002.

8. Spiegel S and Milistein S: Sphingosine 1-phosphate, a key cell signaling molecule. J Biol Chem 277: 25851-25854, 2002.

9. Takuwa Y, Okamoto Y, Yoshioka K and Takuwa N: Sphingosine 1-phosphate signaling and biological activities in the cardiovascular system. Biochem. Biophys Acta 1781: 483-488, 2008.

10. Ito S, Iwaki S, Koike K, Yuda Y,Nagasaki A, Ohkawa R, Yatomi Y, Furumoto T, Tsutsui H, Sobel BE and Fujii S: Increased plasma Sphingosine 1-phosphate in obese individuals and its capacity to increase the expression of plasminogen activator inhibitor-1 in adipocytes. Coron Artery Dis 24: 642-650, 2013.

11. Fink T, Kazlauskas A, Poellinger L, Ebbesen P and Zachar V: Identification of a tightly regulated hypoxia-response element in the promoter of human plasminogen activator inhibitor-1. Blood 99: 2077-2083, 2002.

12. Zagorska A and Dulak J: HIF-1: The knowns and unknowns of hypoxia sensing. Acta Biochim Pol 51: 563-585, 2004.

13. Ader I, Brizuela L, Bouquerel P, Malavaud B and Cuvillier O: Sphingosine kinase 1: A new modulator of hypoxia inducible factor 1alpha during hypoxia in human cancer cells. Cancer Res 68: 8635-8642, 2008.

14. Leong WI and Saba JD: S1P metabolism in cancer and other pathological conditions. Biochimie 92: 716-723, 2010.

15. Cuvillier $\mathrm{O}$ and Ader I: Hypoxia-inducible factors and sphingosine 1-phosphate signaling. Anticancer Agents Med Chem 11: 854-862, 2011. 
16. Livak KJ and Schmittgen TD: Analysis of relative gene expression data using real-time quantitative PCR and the 2(-Delta Delta C (T)) Method. Methods 25: 402-408, 2001.

17. Imagawa S, Fujii S, Dong J, Furumoto T, Kaneko T, Zaman T, Satoh Y, Tsutsui H and Sobel BE: Hepatocyte growth factor regulates $\mathrm{E}$ box-dependent plasminogen activator inhibitor type 1 gene expression in HepG2 liver cells. Arterioscler Thromb Vasc Biol 26: 2407-2413, 2006.

18. Dong J, Fujii S, Li H, Nakabayashi H, Sakai M, Nishi S, Goto D, Furumoto T, Imagawa S, Zaman TA and Kitabatake A: Interleukin- 6 and mevastatin regulate plasminogen activator inhibitor-1 through CCAAT/enhancer-binding protein- $\delta$. Arterioscler Thromb Vasc Biol 25: 1078-1084, 2005.

19. Olivera A, Kohama T, Tu Z, Milstien S and Spiegel S: Purification and characterization of rat kidney sphingosine kinase. J Biol Chem 273: 12576-12583, 1998.

20. Dimova EY, Jakubowska MM and Kietzmann T: CREB binding to the hypoxia-inducible factor-I responsive elements in the plasminogen activator inhibitor-I promotor mediates the glucagon effect. Thromb Heamost 98: 296-303, 2007.

21. Dong J, Fujii S, Imagawa S, Matsumoto S, Matsushita M, Todo S, Tsutsui H and Sobel BE: IL-1 and IL-6 induce hepatocyte plasminogen activator inhibitor-1 expression through independent signaling pathways converging on C/EBPdelta. Am J Physiol Cell Physiol 292: 209-215, 2007.

22. Jung SY, Song HS, Park SY, Chung SH and Kim YJ: Pyruvate promotes tumor angiogenesis through HIF-1-dependent PAI-1 expression. Int J Oncol 38: 571-576, 2011.

23. Nakayama N, Nakamura T, Okada H, Iwaki S, Sobel BE and Fujii S: Modulators of induction of plasminogen activator inhibitor type-1 in HepG2 cells by transforming growth factor- $\beta$. Coron Artery Dis 22: 468-478, 2011.

24. Anelli V, Gault CR, Cheng AB and Obeid LM: Sphingosine kinase 1 is up-regulated during hypoxia in U87MG glioma cells Role of hypoxia-inducible factors 1 and 2. J Biol. Chem 283: 3365-3375, 2008.

25. Michaud MD, Robitaille GA, Gratton JP and Richard DE: Sphingosine-1-phosphate: A novel nonhypoxic activator of hypoxia-inducible factor-1 in vascular cells. Arterioscler Thromb Vasc Biol 29: 902-908, 2009.
26. Kalhori V, Kemppainen K, Asghar MY, Bergelin N, Jaakkola P and Törnquist K: Sphigosine-1-phosphate as a regulator of hypoxia-induced factor-1 $\alpha$ in thyroid follicular carcinoma cells. PLoS One 8: e66189, 2013.

27. Brakch N, Dormond O, Bekri S, Golshayan D, Correvon M, Mazzolai L, Steinmann B and Barbey F: Evidence for a role of sphingosine-1 phosphate in cardiovascular remodelling in Fabry disease. Eur Heart J 31: 67-76, 2010.

28. Moore DF, Kaneski CR, Askari H and Schiffmann R: The cerebral vasculopathy of Fabry disease. J Neurol Sci 257: 258-263, 2007.

29. Welch CL, Sun Y, Arey BJ, Lemaitre V, Sharma N, Ishibashi M, Sayers S, Li R, Gorelik A, Pleskac N, et al: Spontaneous atherothrombosis and medial degradation in $\mathrm{Apoe}^{-/}, \mathrm{Npcl}^{-/-}$mice. Circulation 116: 2444-2452, 2007.

30. Yatomi Y, Igarashi Y, Yang L, Hisano N, Qi R, Asazuma N, Satoh K, Ozaki Y and Kume S: Sphingosine 1-phosphate, a bioactive sphingolipid abundantly stored in platelets, is a normal constituent of human plasma and serum. J Biochem 121: 969-973, 1997.

31. Hisano Y, Nishi T and Kawahara A: The functional roles of S1P in immunity. J Biochem 152: 305-311, 2012.

32. Hillmen P, Muus P, Dührsen U, Risitano AM, Schubert J, Luzzatto L, Schrezenmeier H, Szer J, Brodsky RA, Hill A, et al: Effect of the complement inhibitor eculizumab on thromboembolism in patients with paroxysmal nocturnal hemoglobinuria. Blood 110: 4123-4128, 2007.

33. Nguyen Dinh Cat A, Escoubet B, Agrapart V, Griol-Charhbili V, Schoeb T, Feng W, Jaimes E, Warnock DG and Jaisser F: Cardiomyopathy and response to enzyme replacement therapy in a male mouse model for Fabry disease. PLoS One 7: e33743, 2012.

34. Helley D, de Latour RP, Porcher R, Rodrigues CA, Galy-Fauroux I, Matheron J, Duval A, Schved JF, Fischer AM and Socié G; French Society of Hematology: Evaluation of hemostasis and endothelial function in patients with paroxysmal nocturnal hemoglobinuria receiving eculizumab. Haematologica 95: 574-581, 2010.

35. Anthony MT, Zeigler ZR, Lister J, Raymond JM, Shadduck RK, Kramer RE, Gryn JF, Rintels PB, Besa EC, George JN, et al: Plasminogen activator inhibitor (PAI-1) antigen levels in primary TTP and secondary TTP post-bone marrow transplantation. Am J Hematol 59: 9-14, 1998 